\title{
Floristic diversity of Laokhowa wildlife sanctuary, Assam, India
}

\author{
Chaya Deori ${ }^{\boxplus}$ and S. R. Talukdar \\ Botanical Survey of India, Eastern Regional Centre, Shillong-793003, India \\ 凶Corresponding author: drchayadeoribsi@gmail.com
}

\section{भारत के लाओखोवा वन्यजीव अभयारण्य, असम की पुष्पीय पादप विविधता}

\author{
छाया देउरी व एस. आर. तालूकदार
}

\section{सारांश}

इस शोध पत्र में लाओखोवा वन्यजीव अभयारण्य का पुष्पीय पादप विवरण है, जिसमें 303 वंश के 409 टैक्सा एवं आवृतबीजी व पर्णांग के 105 कुल शामिल हैं। इनमें द्विबीजपत्रीय पादपों की 281 जातियां, 01 उपजाति, 3 प्रभेद और एकबीजपत्री पादपों की 104 जातियां हैं, जबकि पर्णांगों की 20 जातियां शामिल हैं। यहाँ 266 जड़ी बूटी जातियां, 49 वृक्ष, 63 क्षुप और लघु क्षुपों की 31 जातियां हैं। यहां प्राकृतवास के आधार पर 351 पादप स्थलीय, 09 अधिपादप, 45 जलीय और 04 परजीवी पौधे हैं। प्रस्तुत शोधपत्र में अभयारण्य की वनस्पति का संक्षित्त विवरण, पौधों की आर्थिक उपयोगिता और संरक्षण उपायों का विवरण दिया गया है।

\section{ABSTRACT}

The paper provides a floristic account of Laokhowa Wildlife Sanctuary which includes 409 taxa belonging to 303 genera and 105 families of Angiosperms and Pteridophytes. The dicotyledons are represented by 281 species, 1 subspecies, 3 varieties, monocotyledons are with 104 species; while pteridophytes with 20 species. There are 266 herbaceous species, 49 trees, 63 shrubs and 31 under shrubs. Habitats wise, there are 351 species of terrestrial, 9 epiphytes, 45 aquatic and 4 parasites. A brief account of vegetation of the sanctuary, economic potential of plants, threats and conservation measures have been provided.

Keywords: Floristic diversity, Laokhowa Wildlife Sanctuary, Vegetation, Assam, Economic potential, Conservation.

\section{INTRODUCTION}

Laokhowa wildlife sanctuary is located in the central Assam near the southern bank of River Brahmaputra in Nagaon district of Assam ( $26^{\circ} 30^{\prime} \mathrm{N}$ to $26^{\circ} 32^{\prime} \mathrm{N}$ Latitude and $92^{\circ} 40^{\prime} \mathrm{E}$ to $92^{\circ} 47^{\prime} \mathrm{E}$ Longitude). The sanctuary covers an area of $70.13 \mathrm{sq}$. km. and has a common boundary with Burachapori Wildlife Sanctuary (Fig. 1). The sanctuary has a proud legacy of being a protected area for over 110 years. The sanctuary was first identified and demarked by the colonial British Government as a game Reserve in 1907 and declared as a wildlife sanctuary in 1972. Before 1983 the sanctuary was the natural home for large populations of one horned Rhinoceros unicornis which was severely affected during subsequent years and presently the sanctuary is devoid of even a single Rhino. 
Many other wild animals such as Asiatic Elephant, Wild Buffalo, Hog deer, Barking deer, Tiger, Leopard, Civets, Wild pig are found in the sanctuary. A good number of both local and migratory birds, endemic species of fishes, various amphibian species, reptiles and several species of butterflies are also found here. The sanctuary being a flood plain of the river Brahmaputra, its ecosystem is a unique; combination of grassland, wetland and different riparian forest types (Nath, 2012; 2012a; Nath \& Sarma, 2012). However, the sanctuary is facing grave threats in the form of encroachment of sanctuary land for cultivation, dwelling, community grazing ground, domestication cattle and felling of timber and firewood value plants. No authenticate information on plants of the sanctuary is available except Hooker, 1875-1897; Kanjilal \& al., 193440 and Chowdhery \& al., 2005. In the present work an attempt was made to analyze the vegetation and plant composition of the sanctuary particularly emphasizing the native plants and economic potential of plants, threats and conservation measures.

\section{CLIMATE}

The climate of the sanctuary is typical monsoonal and remains highly warm and humid throughout the year.
The region receives rain during summer due to early commencement of south-west monsoon with an average of 250-300 cm and winters are usually cold and dry. The maximum temperature attained during the summer is $26^{\circ}-34^{\circ} \mathrm{C}$ and minimum during the winter is $8^{\circ}-15^{\circ} \mathrm{C}$.

\section{MATERIALS AND METHOD}

The study on the flora of the Laokhowa Wildlife Sanctuary was carried out from April 2013 to March 2016. Four field tours were conducted in the four different seasons of the year and collected 635 voucher specimens along with GPS co-ordinations and colour photographs. All the collected plant specimens were identified with the help of relevant literatures (Hooker, 1875-1897; Kanjilal \& al., 1934-40 and Chowdhery \& al., 2005) and with consultation with herbarium specimens housed in ASSAM. All the earlier collections from the sanctuary lodged at ASSAM has also been studied.

\section{OBSERVATIONS}

Following forest types are observed in the sanctuary:

Scrub Forests: This type of forest is mainly found in northern side of the sanctuary. The main dominant

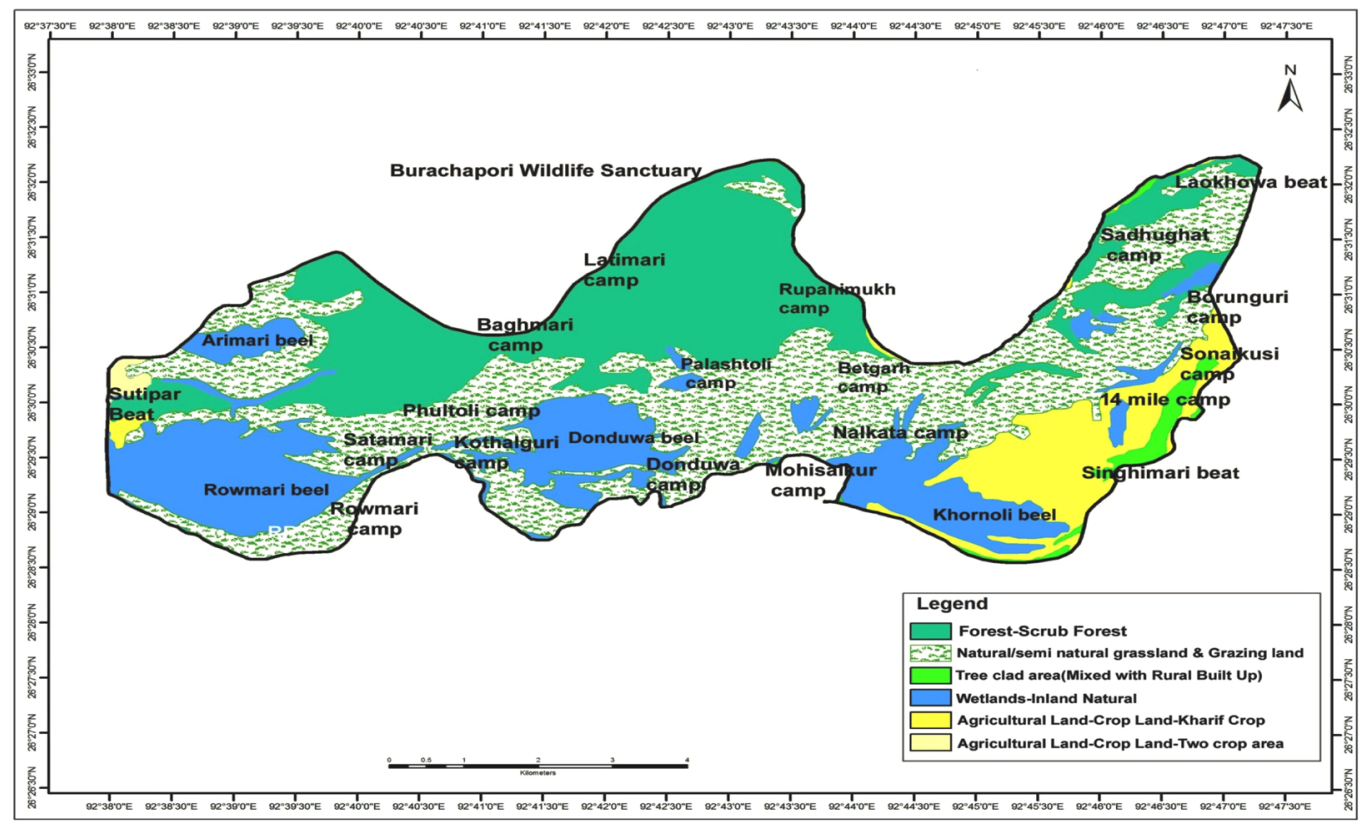

Fig. 1: Map of Laokhowa Wild life sanctuary.

(Source: North Eastern Space Applications Centre, Umaim, Ri- Bhoi District, Meghalaya.) 
species are Ardisia humilis, A. icara, A. paniculata, A. solanacea, Caesalpinia bonduc, C. cucullata, Casearia vareca, Clerodendrum cordatum, C. indicum, C. japonicum, Combretum wallichii var. flagrocarpum, Embelia tsjeriam-cottam, Flemingia strobilifera, Glycosmis pentaphylla, Grewia laevigata, Leea asiatica, Marsdenia tenacissima, Mussaenda roxburghii, Psychotria montana, Senna occidentalis, S. oxyphylla, Thevetia neriifolia, Uncaria sessilifructus etc. The climbers and scandent lianas are mainly Aganope thyrsiflora, Asparagus racemosus, Cissus adnata, Clematis cadmia, Cissampelos pareira, Coccinia grandis, Dioscorea bulbifera, Ichnocarpus frutescens, Ipomoea cheirophylla, I. obscura, Lygodium japonicum, L. flexuosum, Momordica dioica, Mucuna pruriens, Passiflora foetida, Stephania japonica, Smilax ovalifolia, Tetrastigma angustifolium etc. The herbaceous vegetation mainly composed of Achyranthes aspera, Adenostemma lavenia, Alocasia fornicata, Carex hebecarpa, Cheilocostus speciosus, Colocasia esculenta, Commelina benghalensis, Desmodium triflorum, Murdannia nudiflora, Persicaria chinensis, Zingiber rubens etc. Species belonging to the families Lamiaceae, Scrophulariaceae, Capparaceae, Cannabaceae were also seen growing. The terrestrial ferns like Cyclosorus aridus, C. tylodes, Diplazium dilatatum, D. esculentum, Helminthostachys zeylanica, Thelypteris esquirolii etc., and a lone ground orchid Zeuxine nervosa was found.

Barringtonia swamp forest: This type of forest occurs in the low-lying areas which remains inundated during the rainy season. This type of forest is mainly composed of Barringtonia acutangula and sparsely Bischofia javanica, Bombax ceiba, Butea monosperma, Bridelia retusa, Crateva nurvala, Derris cuneifolia, Erythrina fusca, Glochidion coccineum, Streblus asper etc. The ground vegetation is seasonally dominated by Carex hebecarpa, Ficus heterophylla, Potentilla indica and patches of Calamus tenuis, Eichhornia crassipes, Ludwigia adscendens, Lasia spinosa etc. Epiphytes mainly orchids and ferns like Gastrochilus obliquus, Papilionanthe teres, Rhynchostylis retusa, Lemmaphyllum microphyllum, Pseudodrynaria coronans, Pyrrosia lanceolata etc., are found.

The Grassland and Savannah Grassland: This type of vegetation is concentrated in the central part of the sanctuary. The ground vegetation of the grasslands composed of Acroceras zizanioides, Axonopus compressus, Chrysopogon aciculatus, C. zizanioides, Cynodon dactylon, Dactyloctenium scindicum, Eleusine indica, Imperata cylindrica, Paspalidium flavidum etc., and sparsely growth of Melilotus indicus are seen. Apart from the above grasses the Savannah grasslands are composed of tree species like Barringtonia acutangula, Bombax ceiba, Ficus lamponga, Ilex khasiana, Ziziphus jujuba etc., and some shrubs like Flemingia strobilifera, Ricinus communis etc., are found.

Tree Clad area or Plantation forest is mainly concentrated in the north-east part of the sanctuary. These areas are mainly composed of Albizia procera plantation and some trees of Alstonia scholaris, Bombax ceiba, Delonix regia, Erythrina fusca, Lagerstroemia speciosa, Mallotus nudiflorus, M. philippensis, M. repandus, Moringa oleifera etc., are seen. The ground vegetation is dominated by Floscopa scandens, Gnaphalium purpureum, Grangea maderaspatana, Hydrolea zeylanica, Impatiens tripetala, Lasia spinosa, Mimosa pudica, Oldenlandia corymbosa etc.

The wetland vegetation is mainly concentrated in the low-lying water filled areas of the Sanctuary. These areas are concentrated of wetland flora with aquatic macrophytic species. The aquatic macrophytic plants are composed of (1). Pure aquatic macrophytes and (2). Semi- aquatic macrophytes. The pure aquatic macrophytes can be classified into various sub groups based on the state of growth in their habitats such as a. Free floating aquatic macrophytes (Azolla pinnata, Eichhornia crassipes, Hydrocharis dubia, Lemna perpusilla, Pistia stratiotes, Salvinia cuculata, Trapa natans, Utricularia aurea etc.); b. Free submerged aquatic macrophytes (Ceratophyllum demersum etc.); c. Anchored floating aquatic macrophytes (Euryale ferox, Hygroryza aristata, Ipomoea aquatica, Nelumbo nucifera, Nymphaea nouchali, Nymphaea rubra, Nymphoides cristata, Nymphoides indica etc.) and d. Anchored submerged aquatic macrophytes (Hydrilla verticillata, Ottelia alismoides, Potamogeton crispus, Potamogeton octandrus, Vallisneria spiralis etc.).

The semi aquatic macrophytes are Achyranthes aspera, Alternanthera philoxeroides, Alternanthera pungens, Amaranthus spinosus, Amaranthus viridis, Ammannia baccifera, Axonopus compressus, Bacopa monnierioides, Cenchrus americanus, Centella asiatica, Coix lacryma-jobi, Commelina appendiculata, Commelina benghalensis, Commelina sikkimensis, Cucumis melo, Cuphea carthagenensis, Cynodon dactylon, Cyperus compressus, C. iria, C. platystylis, C. rotundus, C. tenuispica, Dactyloctenium scindicum, Eclipta prostrata, Enydra fluctuans, Eragrostis unioloides, Fimbristylis dichotoma, F. squarrosa, Ipomoea carnea, Isachne clarkei, Ludwigia adscendens, L. hyssopifolia, L. octovalvis, Merremia umbellata, Mollugo pentaphylla, Murdannia nudiflora, Nelsonia canescens, Nicotiana plumbaginifolia, 
Oxalis corniculata, Panicum paludosum, Paspalidium punctatum, Paspalum scrobiculatum, Persicaria hydropiper, $P$. orientalis, Phragmites karka, Phyla nodiflora, Polygonum plebeium, Polytoca digitata, Pouzolzia hirta, Rotala rotundifolia, Rumex nepalensis, Rungia pectinata, Schoenoplectiella articulata, S. erecta, Stenoseris graciliflora, Xanthium strumarium etc. (Talukdar \& Deori, 2016)

Table 1: Statistical synopsis of flora of Laokhowa Wildlife Sanctuary, Assam

\begin{tabular}{lllll}
\hline $\begin{array}{l}\text { Taxonomic } \\
\text { Group }\end{array}$ & Families & Genera & Species & $\begin{array}{l}\text { Varieties/ } \\
\text { Subspecies }\end{array}$ \\
\hline $\begin{array}{l}\text { Pterido- } \\
\text { phytes }\end{array}$ & 12 & 17 & $20(5 \%)$ & \\
$\begin{array}{l}\text { Dicotyledons } \\
76\end{array}$ & 218 & $281(70 \%)$ & $\begin{array}{l}\text { 1sub- } \\
\text { species, } \\
\text { 3varieties }\end{array}$ \\
$\begin{array}{l}\text { Monocotyle- } \\
\text { dons }\end{array}$ & 17 & 68 & $104(25 \%)$ & \\
Total & 105 & 303 & 405 & 4 \\
\hline
\end{tabular}

Table 2: Dominant families of Laokhowa Wildlife Sanctuary

\begin{tabular}{llll}
\hline Sl. No. & Families & Genera & Species \\
\hline 1 & Poaceae & 28 & 38 \\
2 & Fabaceae & 16 & 23 \\
3 & Cyperaceae & 6 & 23 \\
4 & Asteraceae & 20 & 20 (1var.) \\
5 & Euphorbiaceae & 12 & 19 \\
6 & Solanaceae & 5 & 10 \\
7 & Cucurbitaceae & 7 & 9 \\
8 & Caesalpiniaceae & 5 & 9 \\
9 & Polygonaceae & 3 & 9 \\
10 & Commelinaceae & 3 & 8 \\
\hline
\end{tabular}

\section{Floristic analysis and life forms}

The study on the flora of Laokhowa Wildlife Sanctuary revealed occurrence of 405 species, 1 subspecies, 3 varieties belonging 303 genera and 105 families of Angiosperms and Pteridophytes. The Angiosperms consist of 385 species, 1 subspecies 3 varieties distributed in 286 genera and 93 families, of which the dicots represented by 281 species, 1 subspecies, 3 varieties and monocot by 104 species. The Pteridophytes comprise of 20 species, belonging to 17 genera and 12 families. The most dominant family is Poaceae with 38 species which is followed by Fabaceae, Cyperaceae, (23 Species) each, Asteraceae, (20 species) and Euphorbiaceae (19 species) etc. Table 2 shows the first 10 dominated families in the sanctuary. The study revealed occurrence of 266 maximum herbaceous species 49 trees, 63 shrubs and 31 under shrubs. Occurrence of maximum herbaceous species is due to high anthropogenic disturbance in the sanctuary (Talukdar \& Deori, 2016 a).

\section{Threats}

The floristic composition and fauna of Laokhowa Wildlife Sanctuary is facing major threats due to biotic and abiotic factors. The vegetation and floristic composition is being negatively influenced due to extraction of firewood and timber by villagers surrounding the sanctuary. Encroachment of forest land by developing agriculture land in the surrounding regions affects the floristic composition of the vegetation and the habitat of wild animals residing in the region. Various invasive species or weeds such as Ageratum conyzoides, Annona reticulata, Eichhornia crassipes, Mimosa pudica, Physalis minima, Ricinus communis, Zephyranthes minuta etc., imparts threat to the growth and propagation of the native species of the sanctuary. Moreover the massive soil erosion during the

Table 3: Analysis of different life forms of Angiosperms and Pteridophytes in Laokhowa Wildlife Sanctuary, Assam

\begin{tabular}{|c|c|c|c|c|c|c|c|c|c|c|c|}
\hline $\begin{array}{c}\text { Trees } \\
49 \\
(12 \%)\end{array}$ & \multicolumn{4}{|c|}{$\begin{array}{l}\text { Shrubs } \\
63(15 \%)\end{array}$} & \multicolumn{5}{|c|}{ Herbs $266(65 \%)$} & \multicolumn{2}{|c|}{$\begin{array}{l}\text { Under } \\
\text { shrubs } \\
31(8 \%)\end{array}$} \\
\hline 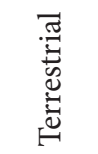 & 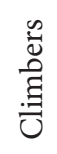 & 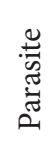 & 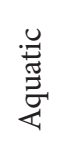 & 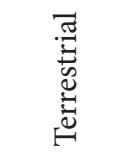 & 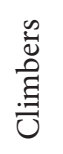 & 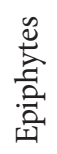 & 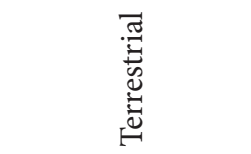 & 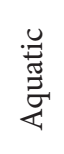 & 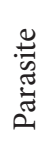 & 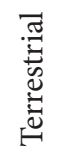 & $\begin{array}{l}\stackrel{0}{0} \\
\stackrel{\pi}{Z}\end{array}$ \\
\hline 49 & 17 & 3 & 1 & 42 (1var.) & 37 & 9 & $\begin{array}{c}177 \text { (177sp., } 2 \text { sub } \\
\text { sp.2 var) }\end{array}$ & 42 & 1 & 29 & 2 \\
\hline
\end{tabular}



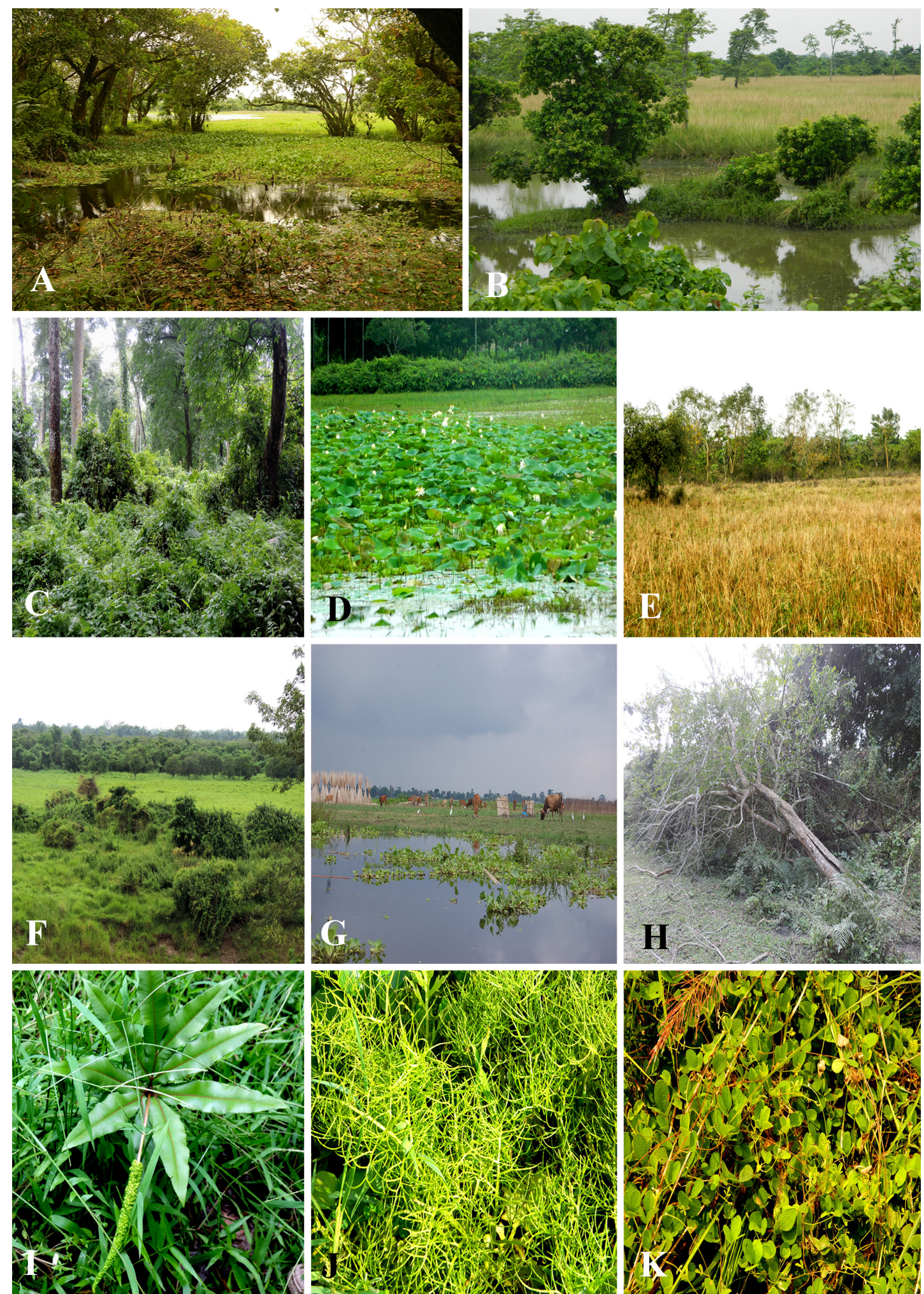

Plate 1: A. Swampy forest area in Laokhowa Wildlife sanctuary, B. Patches of Barringtonia acutangula (L.) Gaertn. in grassland vegetation, C. Secondary forest, D. Vigorous growth of Nelumbo nucifera in the wetlands, E. Grassland vegetation, F. Savannah grassland vegetation, G. Encroachment of portions of wetlands of Laokhowa Wildlife Sanctuary for cultivation and dwelling, H. Uprooting of trees by wild elephant inside the Laokhowa Wildlife Sanctuary, I. Helminthostachys zeylanica (L.) Hook, J. Ceratopteris thalictroides (L.) Ad. Brongn., K. Cajanus scarabaeoides (L.) Graham ex Wall. 

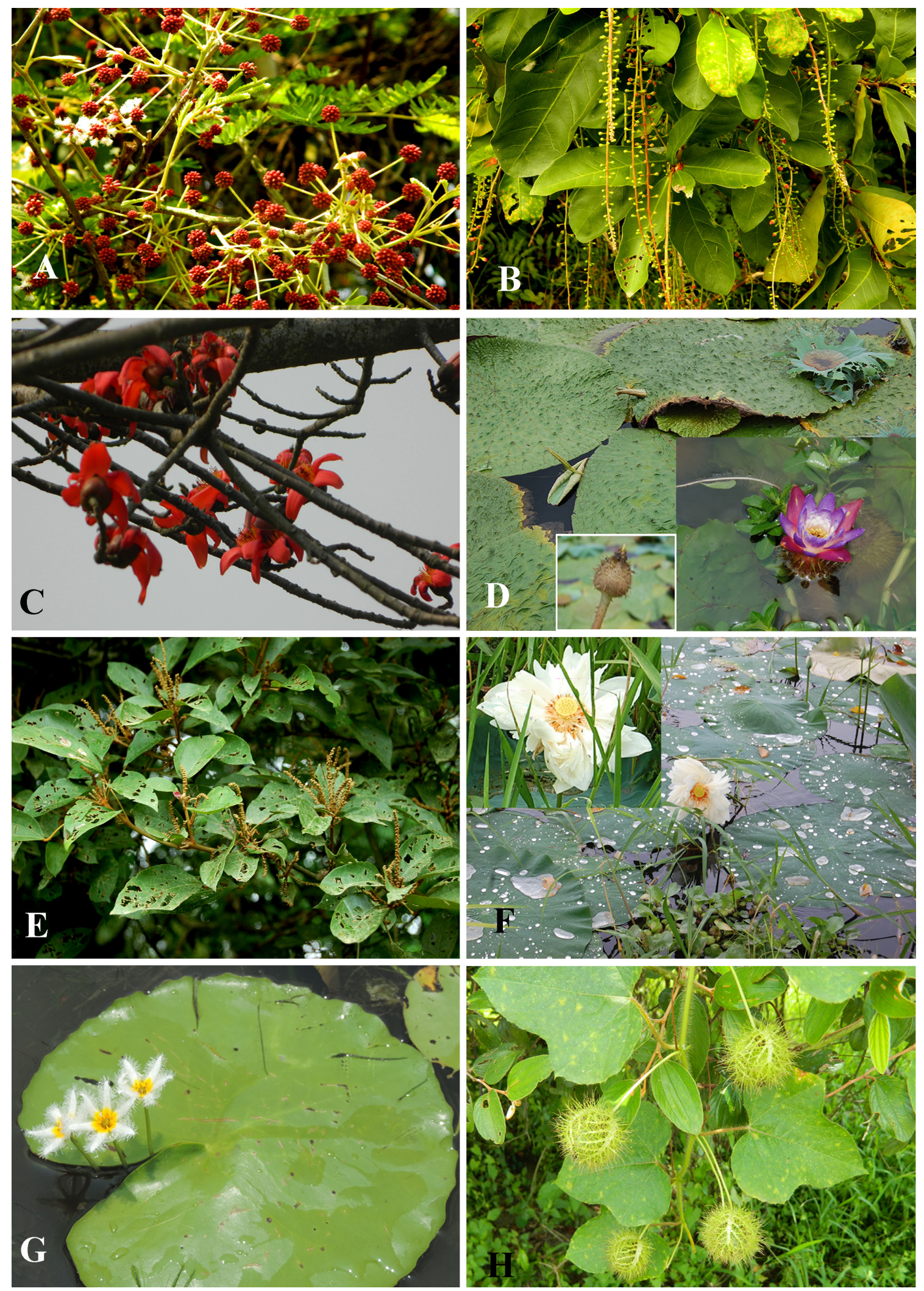

Plate 2: A. Acacia concinna (Willd.) DC., B. Barringtonia acutangula (L.) Gaertn., C. Bombax ceiba L., D. Euryale ferox Salisb, E. Mallotus philippensis (Lam.) Mull. Arg., F. Nelumbo nucifera Gaertn, G. Nymphoides indica (L.) Kuntze, H. Passiflora foetida L. 

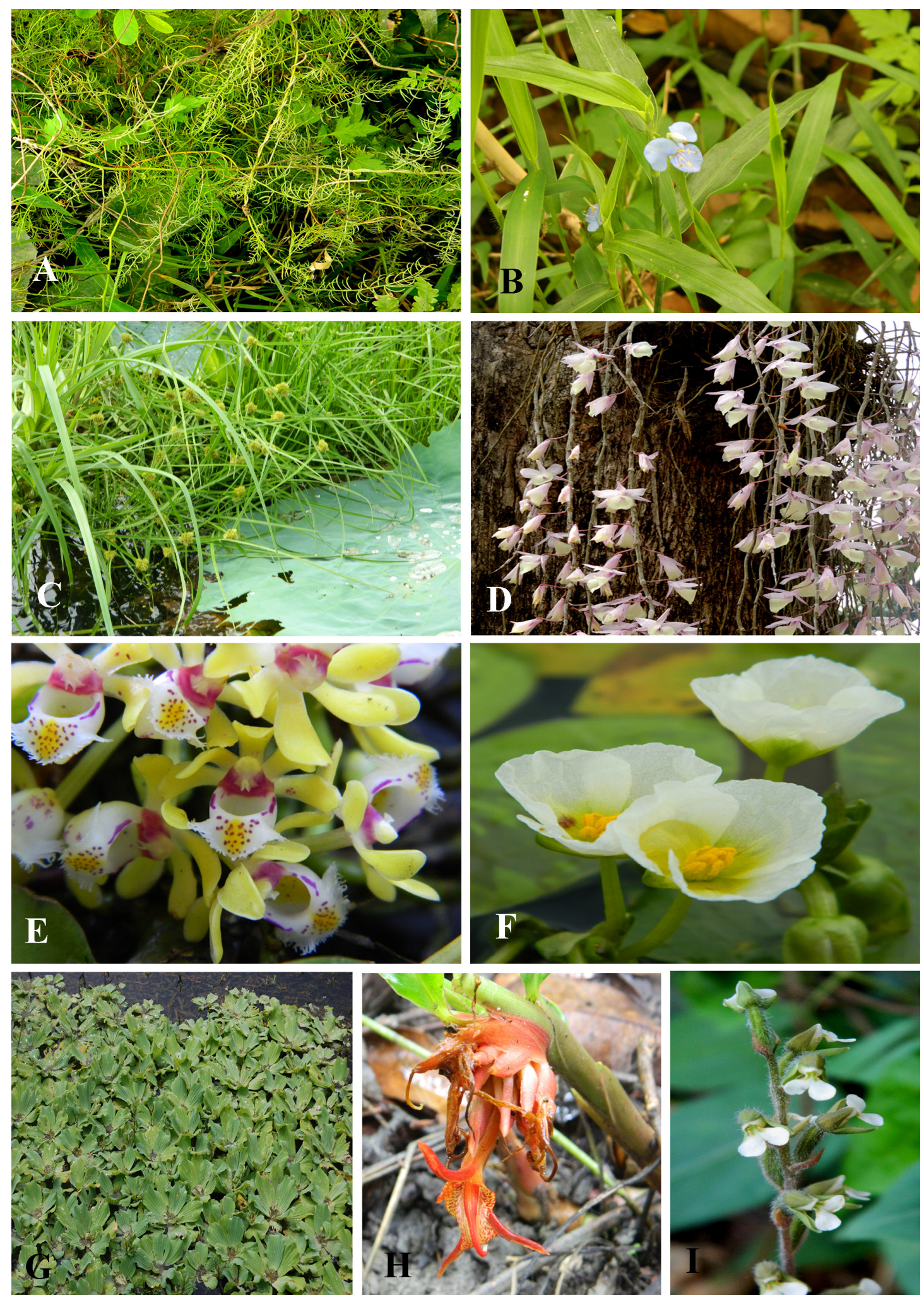

Plate 3: A. Asparagus racemosus Willd, B. Commelina benghalensis L., C. Cyperus cephalotes Vahl, D. Dendrobium aphyllum (Roxb.) C. E. C. Fisch., E. Gastrochilus obliquus (Lindl.) Kuntze, F. Hydrocharis dubia (Blume) Backer, G. Pistia stratiotes L., H. Zingiber rubens Roxb., I. Zeuxine nervosa (Wall. ex Lindl.) Benth. ex Trimen. 
monsoon season also have a négative impact on the vegetation of the sanctuary.

\section{Conservation measures}

The sanctaury authority has taken some plantation measures in some areas of the sanctuary by planting Albizia procera in the fringe areas. These plantations controls the habitat loss and also lessen the degraded forest areas. Restriction to the free extraction of firewood, timber, fishing and cattle rearing inside the sanctuary curb the unnecessary interference in the natural ecosystem. Moreover, creation of awareness among the people for community participation and conservation is also given importance for efficient management of the sanctuary.

\section{DISCUSSION}

The Laokhowa wildlife sanctuary is a unique combination of grassland, wetland and different riparian forest types being a flood plain of the river Brahmaputra. Moreover, our observation also established maximum number of herbaceous elements followed by undershrubs, shrubs and minimum number of trees. The sanctuary comprises of Indo-Malayan elements like Antidesma acidum, Barringtonia acutangula, Cassia fistula, etc. and some tropical American origin plants like Argemone maxicana, Cassia occidentalis, Datura metal, Mimosa pudica etc. As the plain woodland area is disturbed by annual floods, minimum numbers of trees are found growing in the sanctuary of which the dominant ones are Albizia procera, Barringtonia acutangula, Bombax ceiba, Lagerstroemia speciosa, Streblus asper etc. Although the sanctuary is facing threats from biotic and abiotic factors, still a few endangered (Asplenium nidus, Rhynchospora hookeri) and critically endangered (Ceratopteris thalictroides) species were observed (Chowdhery \& al., 2005). Some rare, vulnerable (Gastrochilus obliquus, Euryale ferox) and economic plant species as mentioned were also found. Hence, the Laokhowa wildlife sanctuary apart from harbouring diverse plant

Table 4: Economic importance of some of the species of Laokhowa Wildlife Sanctuary, Assam. (ISLAM, 1990; Sharma, 2004.)

\begin{tabular}{|c|c|c|c|}
\hline Name of the species & Family & Parts used & Uses \\
\hline \multicolumn{4}{|c|}{ Plants as source of food, Beverage and spices } \\
\hline Amaranthus spinosus, A. viridis & Amaranthaceae & Whole plant & Food \\
\hline Centella asiatica & Apiaceae & Whole plant & Food \\
\hline Diplazium esculentum & Athyriaceae & Fronds & Food \\
\hline Commelina benghalensis & Commelinaceae & Seed & Spice \\
\hline Oxalis corniculata & Oxalidaceae & Leaf & Food \\
\hline Citrus medica & Rutaceae & Fruit & Beverage \\
\hline Piper longum & Piperaceae & Fruit & Spice \\
\hline Ceratopteris thalictroides & Parkeriaceae & Whole plant & Food \\
\hline Dioscorea bulbifera & Dioscoreaceae & Tuber & Food \\
\hline \multicolumn{4}{|l|}{ Broom yielding Plant } \\
\hline Sida rhombifolia & Malvaceae & Whole plant & Broom \\
\hline \multicolumn{4}{|l|}{ Plants as fodder } \\
\hline Cynodon dactylon, Eleusine indica & Poaceae & Whole plant & Whole plant \\
\hline \multicolumn{4}{|l|}{ Timber yielding plants } \\
\hline Alstonia scholaris & Apocyanaceae & Wood & Timber \\
\hline Toona ciliata & Meliaceae & Wood & Timber \\
\hline Bischofia javanica, Bridelia retusa & Euphorbiaceae & Wood & Timber \\
\hline Barringtonia acutangula & Lecythidaceae & Wood & Timber \\
\hline
\end{tabular}


Lagerstroemia speciosa

Gmelina arborea

Litsea glutinosa

\section{Dye yielding plants}

Bischofia javanica, Mallotus repandus

Mallotus philippensis

Butea monosperma

\section{Fibre yielding plants}

Lagerstroemia speciosa

Bombax ceiba

Sida rhombifolia

Melochia corchorifolia

Triumfetta rhomboidea

\section{Oil yielding plants}

Celastrus paniculatus

Tamarindus indica

Jatropha curcas, Mallotus philippensis, Ricinus communis

\section{Plants as source of Medicine}

Piper longum

Amaranthus spinosus
Centella asiatica
Alstonia scholaris
Rauvolfia serpentina
Calotropis gigantea
Ageratum conyzoides
Eclipta prostrata

Oroxylum indicum

Cassia fistula

Cannabis sativa

Commelina bengalensis

Cuscuta reflexa

Kyllinga brevifolia

Euphorbia hirta

Sida rhombifolia

Boerhavia diffusa
Lythraceae

Verbenaceae

Lauraceae

Euphorbiaceae

Euphorbiaceae

Fabaceae

Lythraceae
Bombaceae
Malvaceae
Sterculiaceae
Teliaceae

Celastraceae

Caesalpinaceae

Euphorbiaceae

Piperaceae

Amaranthaceae

Apiaceae

Apocynaceae

Apocynaceae

Asclepidiaceae

Asteraceae

Asteraceae

Bignoniaceae

Caesalpinaceae

Cannabaceae

Commelinaceae

Cuscutaceae

Cyperaceae

Euphorbiaceae

Malvaceae

Nyctaginaceae
Wood

Wood

Wood

Bark

Fruit

Flower

Bark

Fruit

Stem

Stem

Stem

Seed

Seed

Seed

Fruit

Whole plant

Whole Plant

Milky latex

Root

Leaf

Leaf

Whole plant

Tender leaf and bark

Pods

Leaf

Leaf

Whole plant

Rhizome

Leaf

Root

Leaf
Timber

Timber

Timber

Dye

Dye

Dye

Fibre

Fibre

Fibre

Fibre

Fibre

Oil

Oil

Oil
Fruit decoction to cure bronchitis.

Whole plant as health tonic.

Whole Plant as tonic.

Milky latex in skin diseases.

Root extract is taken in stomach ache and hypertension.

Leaf used for swelling.

Leaf used as antiseptic.

Whole plant for Jaundice/ Liver trouble.

Tender leaf and bark decoction is taken in dysentery.

Pods are used as purgative.

Leaf for Gonorrhea.

Leaf as abdominal pain.

Whole plant to cure disc prolapsed of waist.

Rhizome for rheumatic pain.

Leaf for skin infection.

Root used as antiseptic.

Leaf extract to cure eye disease. 
Oxalis corniculata

Solanum americanum

Cheilocostus speciosus
Oxalidaceae

Solanaceae

Zingiberaceae
Whole plant

Fruit

Rhizome
Whole plant as abdominal pain.

Fruit as abdominal pain.

Rhizome for rheumatic pain. communities also support wild animals, birds, insects and fishes which is essential in sustaining the biodiversity.

\section{ACKNOWLEDGEMENTS}

The authors are thankful to the, Dr. Paramjit Singh, Director, Botanical Survey of India, Kolkata and Dr. A. A. Mao, Scientist-F, Eastern Regional Centre, Shillong for encouragement and providing facilities.

\section{REFERENCES}

CHOWDHERY, S., A. Kr. NATH, A. BORA, P. P. DAS AND U. PHUKAN. 2005. Assam's Flora: present status of Vascular plants. A.S.T. E.C., Guwahati.

HOOKER J. D. 1875-1897. The flora of British India, Vols 1-7. L. Reeve \& Co. London.

ISLAM, M. 1990. The Flora of Majuli, Singh Mahendra Pal Singh, Dehradun.
KANJILAL U. N., P. C. KANJILAL, A. DAS, R. N. DE AND N. L. BOR. 1934-1940. Flora of Assam. Vol .1-5. Govt. Of Assam, Shillong.

NATH, S. K. 2012. Aquatic macrophytes of Laokhowa Wildlife Sanctuary, Assam, India. Int. J. Eng. Res. App. 2: 1911-1913

NATH, S. K. 2012a. Vegetation and Wildlife of Laokhowa wildlife Sanctuary in Assam, India. Int. J. Eng. Res. App. 3: 248-253.

NATH, S. K. AND S. K. SARMA. 2012. The Status of Laokhowa Wildlife Sanctuary, Assam, India. Int. J. Eng. Res. App. 3: 237-241.

SHARMA, U. K. 2004. Medicinal Plants of Assam. Bishen Singh Mahendra Pal Singh, Dehradun.

TALUKDAR, S. R AND C. DEORI. 2016. Biodiversity potential of the wetlands of Laokhowa wildlife sanctuary, Assam, India. NeBio 7(3):82-92

TALUKDAR, S. R AND C. DEORI. 2016a. Life forms and Biological spectrum of the flora of Laokhowa wildlife sanctuary, Assam, India. NeBio 7(4):151-165. 